\title{
10101 トランスレーショナルリサーチ(16)
}

創 薬

シリーズ(5)

\section{トランスレーショナルリサーチに向けた病理学的研究 \\ 一 消化管がんの新規診断マーカー・治療標的の同定}

\author{
大上 直秀, 仙谷 和弘, 坂本 直也, 安井 弥
}

要約：がん細胞特異的に存在し, 全身正常組織に存在 しない分子は, 分泌タンパク質であれば血清腫瘍マー カーとして, 細胞表面タンパク質であれば治療の標的 分子として期待される。著者らの研究室では, SAGE 法・CAST 法を用いて消化管がん，特に胃がんに特異 性の高い遺伝子の探索を行っている. SAGE 法から同 定された胃がんに特異性の高い遺伝子はREG4, OLFM4，MIA，MMP10，DKK4等で，REG4 遺伝子 がコードする Reg IV, OLFM4 遺伝子がコードするオ ルファクトメジン 4 (olfactomedin 4) はいずれも分泌 タンパク質であり, 胃がん診断における高感度血清マ 一カーである. CAST 法から同定された DSC2 遺伝子 は細胞間接着分子デスモコリン 2 (desmocollin 2) を コードしており, 腸型粘液形質を有する胃がんの細胞 表面に発現していることから, 診断マーカー・治療標 的として有用である.

\section{はじめに}

がんは遺伝子発現異常の病気とも言われる. がん細 胞特異的に存在し, 全身正常組織に存在しない分子は, 診断マーカー・治療の標的分子として有用である。さ らに, 分泌タンパク質であれば血清腫瘍マーカーとし て, 細胞表面タンパク質であれば治療の標的分子とし て期待される(1)。がん細胞特異的な分子の同定を目 的とし, 各種臟器のがん組織を対象に網羅的遺伝子発 現解析が行われてきた。 網羅的遺伝子発現解析の方法 には様々なものがあるが, DNA マイクロアレイ(2) と SAGE 法 (serial analysis of gene expression 法) (3) が 代表的な方法である。これらは, 遺伝子発現という観 点から解析を行う方法であり, がんに特異性の高い分 子を同定できるが，同定した分子が必ずしも分泌タン パク質, 細胞表面タンパク質であるわけではない. 一 方, タンパク質の局在という観点から解析する方法も 開発されている.がん細胞の培養液あるいは細胞膜分 画を材料に二次元電気泳動を行えば，分泌タンパク質
あるいは膜貫通タンパク質を網羅的に同定できる。し かし, タンパク質の構造は複雑であり, その同定が困 難である場合が多い. CAST法 (Escherichia coli ampicillin secretion trap 法) (4) はシグナルシークエン スを欠損させたアンピシリン耐性遺伝子である $\beta$-ラ クタマーゼ遺伝子を組み込んだべクターに解析対象サ ンプルの cDNAを組込み, シークエンスにより分泌夕 ンパク質, 膜貫通タンパク質を同定する方法である.

著者らの研究室では消化管がん, 特に胃がんを材料 にがん関連遺伝子の解析を行っており, SAGE法・ CAST 法を基盤にし, 図 1 に示すストラテジーで胃が 几関連遺伝子の解析を進めている(5). 本稿では, SAGE 法・CAST 法から同定された消化管がんの新規 診断マーカー・治療標的について概説する.

\section{SAGE 法による消化管がん特異的遺伝子の 同定}

\section{1) SAGE 法の原理}

SAGE 法は, 未知, 既知に関わらず遺伝子発現を何 万という単位で網羅的に調べることが可能な方法とし て, 1995 年に Velculescu らによって開発された(3). その基本的な原理は(6), mRNAの poly A テールから 最も近いCATG から下流 10 塩基（これをタグと定義 している）を PCRで増幅後, いくつも直列に連結し, クローニングベクターに組み込み, シークエンスして タグの出現頻度と種類を解析するものである. タグの 配列はわずか 10 塩基であるが，この配列は個々の遺 伝子で特異性が高いことから, 夕グに対応する遺伝子 を特定でき,さらに同じタグの個数を数えれば発現量 が分かる. SAGE 法の場合夕グを連結してシークエン スを読むので, ESTなどの方法と比較し, 効率が 30 倍 以上よくなる. EST法では 1 万個の遺伝子発現を解析 するのに1万クローンのシークエンスを行う必要があ るが, SAGE 法では 330 クローン程度で解析が可能と なる．利点は未知遺伝子の解析も可能であること，定

キーワード：胃がん, SAGE 法, CAST 法

広島大学 大学院 医歯薬学総合研究科 分子病理学研究室 ( $7344-8551$ 広島市南区霞 1-2-3)

E-mail: naoue@hiroshima-u.ac.jp 原稿受領日：2010 年 11 月 8 日, 依頼原稿

Title: Identification of novel diagnostic and therapeutic targets of gastric cancer by SAGE and CAST analysis

Author: Naohide Oue, Kazuhiro Sentani, Naoya Sakamoto, Wataru Yasui 


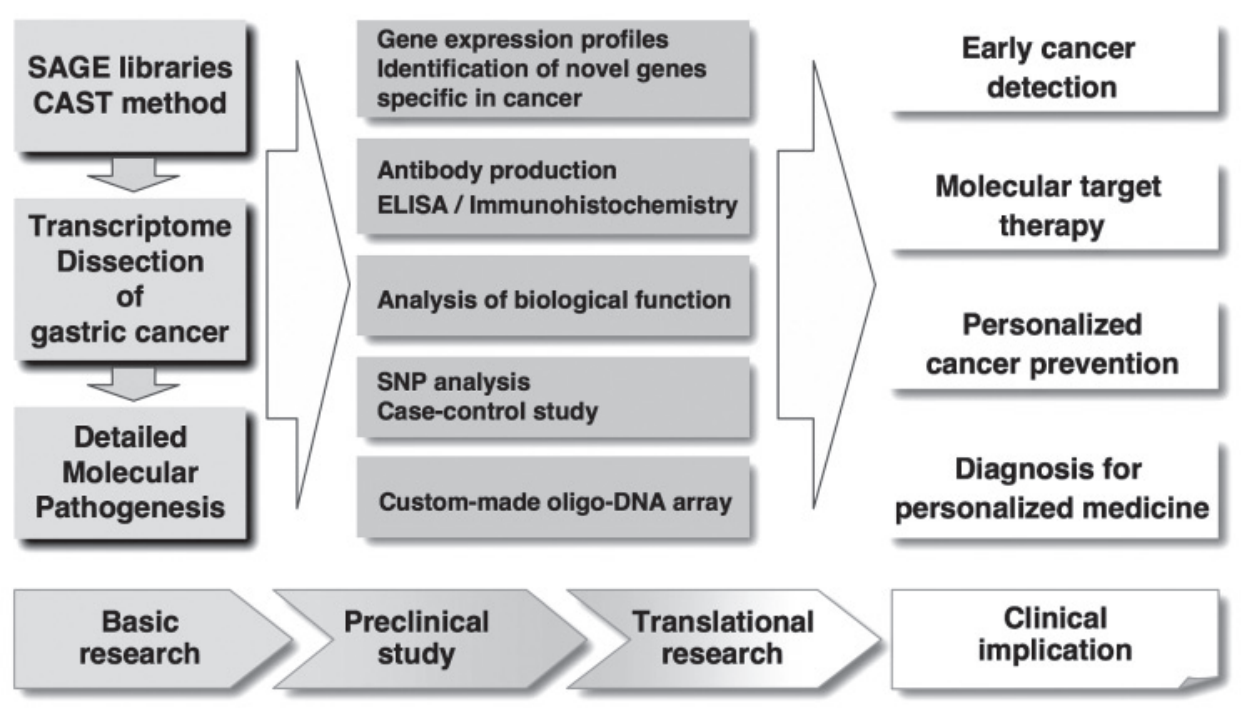

図 1 当研究室における胃がん関連遺伝子同定のストラテジー

量性が高いことである。特に本法はがんにおいて発現 が充進している遺伝子の同定に優れており, 新規診断 マーカー・治療標的の探索に適している. 欠点は多数 のクローンをシークエンスにより解析しなければなら ないため, DNAマイクロアレイと比較し時間とコス トがかかることである。近年, 次世代シークエンサー の登場により，この欠点は克服されつつある.

\section{2）胃がんにおける SAGE 解析}

胃がん組織を用いたSAGE 法による網羅的遺伝子発 現解析は，著者らを含め 4 報が報告されている，著者 らは，原発性の胃がん 4 例とそのリンパ節転移 1 例を 材料にSAGE 法を用いて網羅的遺伝子発現解析を行っ た(7). 合計で約 10 万クローンのシークエンスを行い, 137,706 夕グが得られ，38,903 種類の遺伝子を含んで いた。この SAGEデー夕を相互に比較し，CDH17や $A P O E$ 等の多数の胃がん関連遺伝子を同定した。これ らの結果は胃がん 4 例の解析結果であり, 多数例での 検証作業が必要である。 そこで免疫染色を用いて多数 例での発現解析を行い, 検証作業を進めている. 現在 までに, claudin-18(8) やLi-カドヘリン (Li-cadherin) (9), PLUNC (10) 等の胃がん関連遺伝子を報告してい る.

\section{3）胃がん特異的遺伝子の探索}

正常臓器の SAGEデータと胃がんの SAGEデー夕を 比較し, 胃がん特異的に発現している遺伝子を探索し た結果, APIN, TRAG3, CYP2W1, MIA, MMP10, DKK4, OLFM4, REG4, HORMAD1 の 9 種類の遺伝 子が，がん特異的遺伝子として同定された(11)。これ らの分子は新規診断マーカー・治療標的として期待さ れる. 一方, 胃がんの血清腫瘍マーカーとして, CEA, CA19-9が用いられているが感度は低く, 胃がんの早 期発見には不十分である. 胃がんの新規血清腫瘍マー カーの開発の観点から, 特に分泌タンパク質をコード
している MIA, MMP10, DKK4, OLFM4, REG4に 注目した。

MIA，MMP10，DKK4 に対しては利用可能な抗体が あり，胃がん組織を材料に免疫染色を施行した結果 (11)，いずれのタンパク質もがん細胞に染色され，陽 性率はそれぞれ $31 \% ， 45 \% ， 1 \%$ あった。さらに MIA， MMP10 陽性例は有意に予後不良であった，胃 がん患者の血清中の濃度を ELISA 法で測定すると, 胃 がん診断の感度は MIA では 6\%と低く, 臨床応用は困 難であった，一方，MMP10 の特異性は 85\%とやや低 かったものの, 感度は $94 \%$ ときわて高く, 胃がんの スクリーニングに特に有用と考えられた。同一血清サ ンプルを材料に CEA，CA19-9 も測定したが，感度は それぞれ $10 \%$ 程度と低かった。

$R E G 4$ 遺伝子はもともと 2001 年に炎症性腸疾患で 発現が立進している遺伝子としてクローニングされた ものであり，分泌タンパク質 Reg IVをコードしている. 機能としては EGF受容体 (epidermal growth factor receptor）をリン酸化し，Aktを介して転写因子 AP-1 を活性化し, その標的遺伝子であるサバイビン (survivin) や MMP-7 の発現を誘導する。胃がん組織 を材料に Reg IV の免疫染色を施行したところ (12), $30 \%$ 症例に染色された. MUC2 陽性の杯細胞様の 腫瘍細胞およびクロモグラニン Aが陽性となる神経内 分泌細胞に分化する腫瘍細胞に染色され（図 2), 腸型 粘液形質あるいは神経内分泌への分化に関与している。 胃がん患者の血清中の濃度を ELISA 法で測定すると， 胃がん診断の感度は $36 \%$, 特異性は $99 \%$ であり, 感度 が10\%程度であった CEA，CA19-9 よりもはるかに高 く, Reg IV は胃がん診断に適した血清マーカーである (13).

印環細胞がんは腺がんの 1 つで, 様々な臟器に発生 するが，原発不明がんとして発見されることもめずら 
しくない. 胃原発の印環細胞がんにおいて Reg IV は $100 \%$ の症例で染色されたことから，消化管原発の印 環細胞がんの同定に有用なマーカーになる可能性があ る. そこで胃, 大腸, 肺, 乳腺原発の印環細胞がんを 材料に Reg IV の免疫染色を行ったところ, 胃, 大腸原 発の印環細胞がんでは $100 \%$ の症例が陽性であったの に対し, 肺, 乳腺原発の印環細胞がんでは全く染色さ れなかった (14)。肺腺がんのマーカーであるTTF-1 は, 肺原発印環細胞がんの 89\%に染色されたのに対し, 他 の印環細胞がんでは陰性であった，乳がんのマーカー であるマンマグロビン (mammaglobin), GCDFP15 は 乳腺原発の印環細胞がんに掞いてそれぞれ $100 \%$, 90\%の症例で染色されたが, 他の印環細胞がんでは全 く染色されなかった. 以上から, 原発不明の印環細胞 がんにおいて, Reg IV, TTF-1，マンマグロビン, GCDFP15 の免疫染色は, 原発巣同定に有用であるこ とが分かった。

OLFM4 遺伝子の産物であるオルファクトメジン 4 （olfactomedin 4）に対する抗体は市販のものはなく, 著者らの研究室でモノクローナル抗体を作成した。 OLFM4 は別名 $h G C-1$, GW112 と呼ばれる遺伝子で あり，もともと骨髄芽球からクローニングされたもの である，機能としては, カドヘリンと結合し, 細胞接 着を制御することが報告されているが, 詳細は不明で ある。一方，オルファクトメジン 4 はヒト腸の幹細胞 のマーカーとして注目されている(15). 胃がん組織を 材料にオルファクトメジン 4 の免疫染色を施行した結 果(16), 56\%の症例が陽性であり, 高分化腺がんにお いて高頻度に染色された（図 2). 胃がん全症例につい ては, オルファクトメジン 4 の発現と予後との間に有 意な相関はなかったが, 高分化腺がんに限って検討す ると, オルファクトメジン 4 陽性例は有意に予後良好 であった．胃がん患者の血清中の濃度を ELISA 法で 測定すると, 胃がん診断の感度は $31 \%$, 特異性は $95 \%$ であった。なお， Reg IV とオルファクトメジン 4 を組 み合せて測定した場合, 胃がん診断の感度は $57 \%$ まで 上昇した，特にステージIの胃がんでは，CEAと CA19-9 の組み合わせでは, 感度は 7\%であったが, Reg IV とオルファクトメジン 4 の組み合せでは, 感度
は $52 \%$ と半数以上が陽性になり, 胃がんの早期発見に 有用である。

\section{4）食道がんにおける SAGE 解析}

上記のごとく, 胃がんにおける SAGE 解析は当研究 室を中心に行われているが, 食道がんの SAGE 解析は 進んでいない。そこで食道扁平上皮がんを材料に SAGE 法を用いて網羅的遺伝子発現解析を行った(17). 合計で 14430 タグを同定し, 正常食道の SAGE データ と比較した結果, ADAMTS16 遺伝子が食道扁平上皮 がんで特に発現が充進していた，全身正常組織と食道 扁平上皮がんを材料に, ADAMTS16 の発現をリアル タイム RT-PCR で測定した結果, ADAMTS16の発現 は中枢神経，腎臓で認められたものの低かったのに対 し, 食道扁平上皮がんでは $40 \%$ の症例で高いレベルの 発現を認め, 食道扁平上皮がんに特異性が高いことが 明らかになった. ADAMTS16 は分泌タンパク質であ り, 食道がん細胞株 TE5 の培養液を材料にウェスタン ブロット法 (Western blot) を行った結果, ADAMTS16 タンパク質が検出され，分泌タンパク質であることが 確認された。がんにおける ADAMTS16の機能は全く 不明である.TE5を材料にADAMTS16の発現を siRNA でノックダウンした結果, 細胞増殖能, 浸潤能 いずれもが抑制された。従って, ADAMTS16は食道 がんの新規腫瘍マーカーになる可能性があり, さらに 分子標的としても理想的と考えられる.

\section{CAST 法を用いた細胞表面タンパク質の同定}

\section{1）CAST 法の原理}

CAST 法は, 分泌・膜貫通タンパク質を同定する方 法として 2005 年に Ferguson らによって開発された (4). CAST 法の概略を図 3 に示す(6). まず，分泌に 関与するシグナルシークエンスを欠損させたアンピシ リン耐性遺伝子 ( $\beta$-ラクタマーゼ遺伝子) を組み込ん だベクター（pCAST vector）を準備する．次に欠損さ せたシグナルシークエンスの部分に解析対象サンプル の cDNAを組込みライブラリーを作成する。これらを 大腸菌に導入して, アンピシリン含有培地で培養する。 ここで選択されてくる大腸菌はアンピシリン耐性株で あり, $\beta$-ラクタマーゼ遺伝子が分泌, あるいは大腸菌
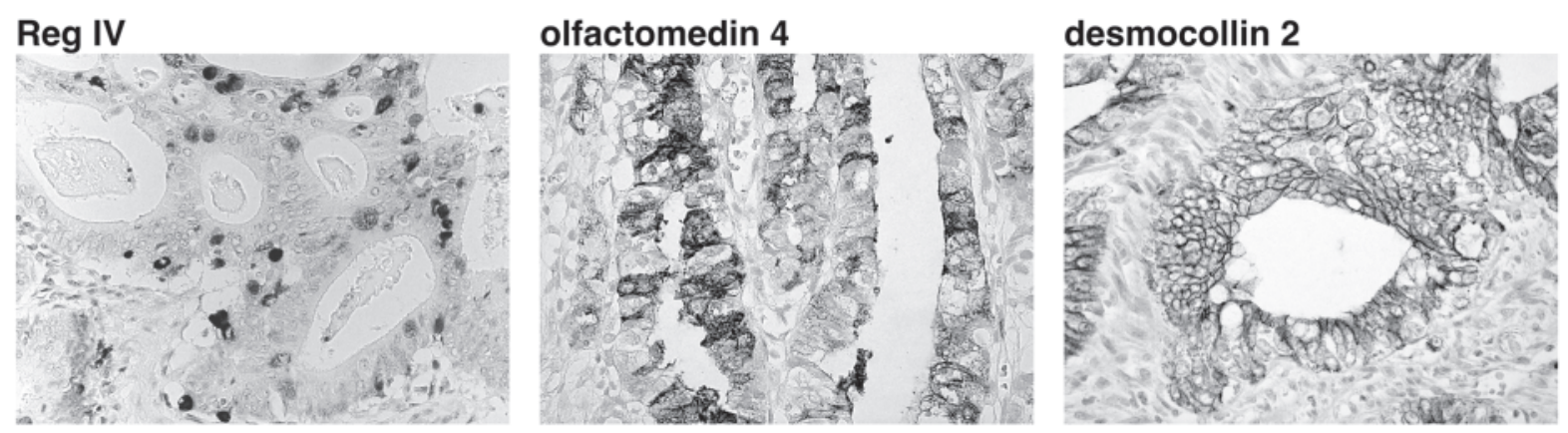

図 2 胃がんにおける Reg IV, オルファクトメジン (olfactomedin) 4, デスモコリン (desmocollin) 2 の免疫染色像 Reg IV とオルファクトメジン 4 はがん細胞の細胞質に, デスモコリン2は細胞膜に染色されている. 


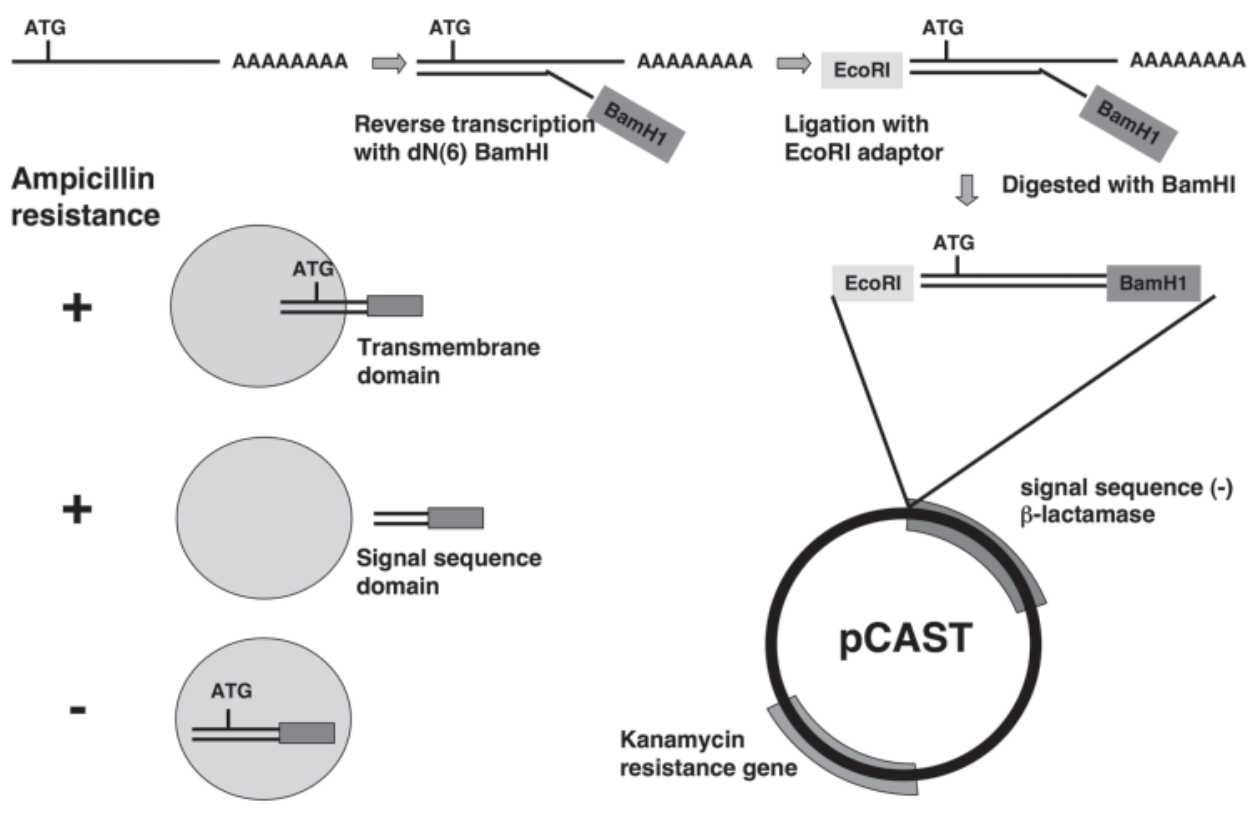

図 3 CAST 法の概略図

の膜上に存在することを意味している，すなわち， pCASTに組込まれた遺伝子配列中に膜貫通ドメイン， あるいはシグナルシークエンスが存在することを示し ている。これらの陽性クローンからプラスミド DNA を抽出し, 塩基配列を解析すれば, 効率よく細胞表 面・分泌タンパク質をコードする遺伝子を同定できる。

\section{2）胃がんにおける CAST 解析}

著者らの研究室では，胃がん細胞株，胃がん組織を 材料にCAST解析を行っている. 胃がん細胞株 MKN-1 と MKN-28 を材料にCAST解析を行った結果, 様々な細胞表面・分泌タンパク質をコードする遺伝子 が同定された (18)。膜タンパク質に焦点をあて，胃が ん組織 42 例を材料にリアルタイム RT-PCR 法で遺伝 子発現を測定した結果, 胃がんにおいて高発現してい る 30 種類の膜タンパク質を同定した。これらのうち, $D S C 2$ 遺伝子は全身正常組織において発現が低く, 胃 がんに特異性が高いことからさらに解析を行った. DSC2 遺伝子は，膜貫通タンパク質デスモコリン 2 (desmocollin 2）をコードしており, 細胞間接着装置であるデスモソ ームを構成しているタンパク質である。胃がん組織 80 例を材料にデスモコリン 2 の免疫染色を施行した 結果, $28 \%$ の症例が陽性であり, がん細胞の細胞膜に 染色され，間質の細胞には染色されなかった（図 2). デスモコリン 2 は腸の転写因子 CDX2 により発現が誘 導されることが知られており, 胃型・腸型の粘液形質 との関連を解析した結果, デスモコリン 2 陽性胃がん は腸型の粘液形質を有する胃がんで発現していること が明らかとなった，従って，デスモコリン 2 は腸型の 粘液形質を有する胃がんのマーカー分子である.

デスモコリン 2 以外にも胃がんにおいて高発現して いる膜タンパク質を多数同定しており, 現在免疫染色
で詳細な解析を進めている。

\section{おわりに}

以上, SAGE 法・CAST 法を用いた胃がんの新規診 断・治療標的の探索について概説した. Reg IV と才 ルファクトメジン 4 を組み合せた血清解析で, ステー ジ I の胃がん患者の半数以上が陽性になるが，スクリ ーニング目的のためには $80 \%$ 以上の感度が必要であり, 組み合わせる分子をさらに追加する必要がある。胃が ん治療において, 分子標的は現在 HER2 のみであるが, HER2 の遺伝子増幅例は 10〜 30\%であり，すべての胃 がんの治療標的になるわけではない. CAST 法を用い て胃がんの細胞表面タンパク質を網羅的に同定し, 治 療標的としての有用性を検討すると共に, 臨床応用を 視野に入れ, 免疫染色可能な抗体を検討あるいは作成 し, 免疫染色像を解析することが重要である.

\section{文献}

1) Yasui W, et al. Cancer Sci. 2004;95:385-392.

2) Lockhart DJ, et al. Nat Biotechnol. 1996;14:1675-1680.

3) Velculescu VE, et al. Science. 1995;270:484-487.

4) Ferguson DA, et al. Cancer Res. 2005;65:8209-8217.

5) Yasui W, et al. Pathol Int. 2009;59:121-136.

6) 大上直秀, 他. 胃がん perspective. 2009;2:92-97.

7) Oue N, et al. Cancer Res. 2004;64:2397-2405.

8) Sanada Y, et al. J Pathol. 2006;208:633-642.

9) Ito R, et al. Virchows Arch. 2005;447:717-722.

10) Sentani K, et al. Mod Pathol. 2008;21:464-475.

11) Aung PP, et al. Oncogene. 2006;25:2546-2557.

12) Oue N, et al. J Pathol. 2005;207:185-198.

13) Mitani Y, et al. Oncogene. 2007;26:4383-4393.

14) Sentani K, et al. Am J Surg Pathol. 2008;32:1182-1189.

15) van der Flier LG, et al. Gastroenterology. 2009;137:15-17.

16) Oue N, et al. Int J Cancer. 2009;125:2383-2392.

17) Sakamoto N, et al. Cancer Sci. 2010;101:1038-1044.

18) Anami K, et al. J Pathol. 2010;221:275-284. 